\title{
$\begin{array}{lllllllllllll}\text { I } & \mathrm{N} & \mathrm{S} & \mathrm{T} & \mathrm{I} & \mathrm{T} & \mathrm{U} & \mathrm{T} & \mathrm{E}\end{array}$
}

\section{Recent Data Show Continued Growth in Supplemental Nutrition Assistance Program Use}

\author{
JESSICA A. CARSON AND WILLIAM W. MEUB
}

$\mathrm{T}$ he Great Recession had profound effects on families across the United States, and economic recovery has been slow. Poverty and unemployment remained high in 2011, and job growth was stagnant. ${ }^{1}$ Amid these signs of a sluggish recovery, social safety net programs have played a key role in supporting vulnerable families. Perhaps one of the most efficient and effective safety net programs, ${ }^{2}$ the Supplemental Nutrition Assistance Program, or SNAP (formerly known as food stamps), has remained particularly important for providing families and children with nutritious foods and alleviating poverty. For example, if SNAP benefits were counted as income, 4.4 percent fewer families would have been considered poor between 2000 and 2009. ${ }^{3}$ SNAP funding also has a multiplicative economic effect on communities, and research shows that every $\$ 5$ increase in benefits generates $\$ 9$ of economic activity. ${ }^{4}$

This brief uses data from the American Community Survey to examine rates of SNAP receipt in 2011, with particular attention to changes since the onset of the recession, and to receipt by family composition, region, and place type (rural, suburban, and central city locations). It also explores SNAP receipt among households at particular risk for food insecurity, such as households containing seniors, a person with a disability, and people in poverty.

\section{SNAP Use Rose in 2011}

As of November 2011, more than 46.3 million people received SNAP benefits nationwide, 2.7 million more than just one year prior. ${ }^{5}$ In 2011, the percent of households reporting SNAP receipt rose by 1.1 percentage points to 13 percent nationally. Central cities had the highest rates of SNAP receipt at 16 percent, closely followed by rural places at 15.6 percent. The suburbs continued to have the lowest rates (10.1 percent in 2011) (see Figure 1). Among all households,

\section{Key Findings}

- In 2011, 13 percent of all households reported receiving Supplemental Nutrition Assistance Program (SNAP) benefits. This represents an increase from 7.7 percent in 2007, reflecting both changes in need and policy.

- The highest rate of SNAP receipt was in central cities ( 16 percent), closely followed by rural areas (15.6 percent).

- Between 2010 and 2011, SNAP receipt increased at a similar pace (by roughly 1 percentage point) in every region and in every place type (rural areas, suburbs, and central cities). Northeastern central cities realized the largest increases since 2007, resulting in the highest rate of SNAP receipt (21.5 percent) of any area by 2011 .

- Single mothers had the highest rate of SNAP receipt, substantially higher than single fathers' rates and three to four times as high as rates among married couples with children.

- More than three-quarters of households reporting SNAP receipt contained one or more workers.

SNAP receipt rose from 2010 levels by just over 1 percentage point. Increases since 2007 were larger, owing in part to legislative changes enacted in 2008 and 2009. ${ }^{6}$ Between 2007 and 2011, SNAP receipt grew the least in suburbs in the Northeast (up 3.9 percentage points) and the most in northeastern central cities (up 8 percentage points). These steep increases in Northeast cities resulted in higher rates there than in any other region or place type, with more than one in five households receiving SNAP in 2011. 
Figure 1. Percent of households RePorting SNAP RECEIPT, BY PLACE TYPE

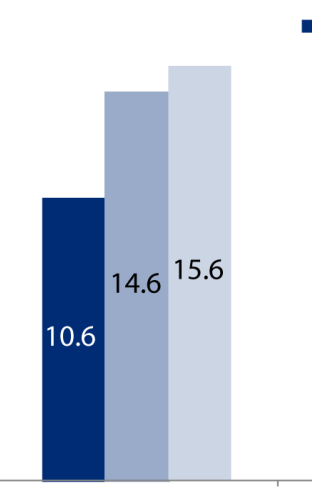

Rural
$-2007-2010-2011$

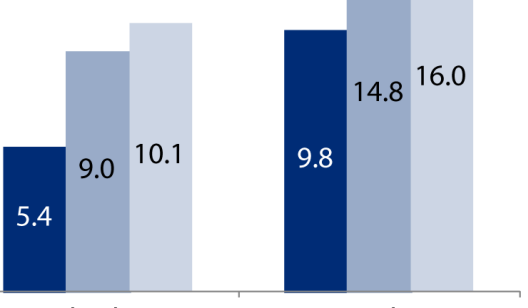

Central City

Note: All differences are statistically significant $(p<0.05)$.

Source: American Community Survey, 2007, 2010, 2011

\section{Single Mothers Still Most Likely to Report SNAP Receipt}

Among all families with children, married couples continued to have the lowest rates of SNAP receipt in 2011, at 11.8 percent. However, even these families were more likely to receive SNAP benefits in 2011 than 2010 in all regions and place types (see Table 1). Despite the generally low rates of SNAP receipt among married couples with children, there is wide variation by place type. For example, 9.4 percent of these families received SNAP in the suburbs, while 15.6 percent did so in rural places. It is worth noting that SNAP receipt among married couples with children increased twofold nationwide since 2007, with particularly large increases in central cities.
Compared with married couple families with children, families headed by single parents reported higher rates of SNAP receipt over time, paired with large increases in receipt since the recession. In 2011, 27.1 percent of single fathers reported SNAP receipt, up 1.7 percentage points since 2010. Rates of receipt among single father families neared one in three in rural places, higher than in any other place type. Single mothers continued to have the highest rates of SNAP receipt, at 44.4 percent in 2011. Rural SNAP receipt was also especially high among single mother families, with more than one in two rural single mother families reporting receipt in 2011. Rates of SNAP receipt among single mothers were highest in midwestern central cities, with 56.6 percent receiving SNAP. Further, even in the northeastern suburbs, where receipt was lowest among single-mother families, one-third were using SNAP in 2011. Despite rates that were already high in 2010, SNAP receipt among single mothers continued to increase, rising by 2.4 percentage points between 2010 and 2011 .

\section{Households Containing Persons Who Are Disabled, Elderly, or Poor Continued to Rely on SNAP}

In addition to families with children, research shows that people with disabilities, seniors, and the poor may be more susceptible to food insecurity. In 2011, 23 percent of households that contained a person with a disability received SNAP (see Table 2 ). Receipt was generally higher in central cities, with as many as 28.6 percent of these households receiving SNAP. Of note is the dramatic increase in SNAP receipt among households containing a person with a disability in northeastern central cities since 2007, increasing from 27.9 percent in 2007 to 39.6 percent in 2011.

TABLE 1. FAMilies With CHILDREN RECEIVING SNAP IN LAST 12 MONTHS, BY FAMILY TYPE, 2011

\begin{tabular}{|c|c|c|c|c|c|c|c|c|c|c|c|c|c|c|c|c|}
\hline & \multicolumn{4}{|c|}{ All Places } & \multicolumn{4}{|c|}{ Rural } & \multicolumn{4}{|c|}{ Suburban } & \multicolumn{4}{|c|}{ Central City } \\
\hline & $\begin{array}{c}\text { Number of } \\
\text { Households } \\
\text { on SNAP }\end{array}$ & $\begin{array}{c}\text { Percent of } \\
\text { Households }\end{array}$ & $\begin{array}{c}\text { Change } \\
\text { Since } 2007\end{array}$ & $\begin{array}{l}\text { Change } \\
\text { Since } 2010\end{array}$ & $\begin{array}{c}\text { Number of } \\
\text { Households } \\
\text { on SNAP }\end{array}$ & $\begin{array}{l}\text { Percent of } \\
\text { Households }\end{array}$ & $\begin{array}{c}\text { Change } \\
\text { Since } 2007\end{array}$ & $\begin{array}{l}\text { Change } \\
\text { Since } 2010\end{array}$ & $\begin{array}{c}\text { Number of } \\
\text { Households } \\
\text { on SNAP }\end{array}$ & $\begin{array}{l}\text { Percent of } \\
\text { Households }\end{array}$ & $\begin{array}{c}\text { Change } \\
\text { Since } 2007\end{array}$ & $\begin{array}{c}\text { Change } \\
\text { Since } 2010\end{array}$ & $\begin{array}{c}\text { Number of } \\
\text { Households } \\
\text { on SNAP }\end{array}$ & $\begin{array}{c}\text { Percent of } \\
\text { Households }\end{array}$ & $\begin{array}{c}\text { Change } \\
\text { Since } 2007\end{array}$ & $\begin{array}{c}\text { Change } \\
\text { Since } 2010\end{array}$ \\
\hline \multicolumn{17}{|l|}{ All Households } \\
\hline U.S. Total & $14,900,000$ & 13.0 & 5.3 & 1.1 & $3,019,586$ & 15.6 & 5.0 & 1.0 & 5,805,271 & 10.1 & 4.8 & 1.1 & 6,119,785 & 16.0 & 6.2 & 1.2 \\
\hline Northeast & $2,664,358$ & 12.7 & 5.1 & 1.1 & 293,431 & 13.8 & 4.6 & 1.4 & $1,031,370$ & 8.2 & 3.9 & 0.9 & 1,339,557 & 21.5 & 8.0 & 1.5 \\
\hline Midwest & $3,417,738$ & 13.2 & 4.9 & 1.0 & 805,396 & 13.3 & 4.4 & 0.8 & $1,217,755$ & 9.8 & 4.3 & 0.9 & $\begin{array}{l}1,394,587 \\
\end{array}$ & 18.7 & 6.3 & 1.3 \\
\hline South & $6,140,380$ & 14.4 & 5.7 & 1.3 & $1,552,720$ & 18.4 & 5.5 & 1.1 & $2,458,363$ & 11.7 & 5.5 & 1.2 & 2,129,297 & 16.0 & 6.2 & 1.4 \\
\hline West & $2,722,166$ & 10.7 & 5.1 & 1.0 & 368,039 & 13.6 & 5.0 & 0.9 & $1,097,783$ & 9.5 & 4.9 & 1.2 & $1,256,344$ & 11.2 & 5.3 & 0.8 \\
\hline \multicolumn{17}{|c|}{ Married Couples with Children } \\
\hline U.S. Total & $2,843,926$ & 11.8 & 5.8 & 1.0 & 572,881 & 15.6 & 6.0 & 0.8 & \begin{tabular}{|l|}
$1,291,761$ \\
\end{tabular} & 9.4 & 5.2 & 1.0 & 979,284 & 14.6 & 7.2 & 1.1 \\
\hline Northeast & 379,632 & 9.0 & 4.6 & 0.9 & 47,122 & 12.2 & 4.9 & 0.8 & 164,127 & 5.7 & 3.2 & 0.7 & 168,383 & 18.0 & 9.2 & 1.5 \\
\hline Midwest & 568,922 & 10.8 & 4.9 & 0.5 & 158,008 & 13.4 & 5.4 & 0.7 & 238,265 & 8.2 & 4.3 & 0.6 & 172,649 & 14.9 & 6.3 & 0.0 \\
\hline South & $1,202,997$ & 13.6 & 6.4 & 1.2 & 286,762 & 18.0 & 6.2 & 0.6 & 567,883 & 11.5 & 6.2 & 1.2 & 348,352 & 15.2 & 7.3 & 1.8 \\
\hline West & 692,375 & 11.9 & 6.6 & 1.1 & 80,989 & 15.6 & 7.4 & 1.5 & 321,486 & 10.8 & 6.4 & 1.3 & 289,900 & 12.5 & 6.7 & 0.8 \\
\hline \multicolumn{17}{|l|}{ Single Fathers } \\
\hline U.S. Total & 843,647 & 27.1 & 12.1 & 1.7 & 169,944 & 32.5 & 12.5 & 2.1 & 351,946 & 23.0 & 11.3 & 2.0 & 321,757 & 30.4 & 13.2 & 1.1 \\
\hline Northeast & 124,287 & 24.9 & 10.5 & 1.6 & 18,313 & 31.3 & 14.0 & 5.6 & 48,452 & 17.5 & 7.0 & 1.0 & 57,522 & 35.1 & 15.1 & 1.7 \\
\hline Midwest & 191,346 & 28.4 & 11.1 & 1.3 & 49,249 & 30.1 & 9.4 & 1.7 & 68,711 & 22.6 & 10.3 & 0.9 & 73,386 & 35.6 & 13.6 & 1.0 \\
\hline South & 324,957 & 28.9 & 13.0 & 1.5 & 75,896 & 34.6 & 13.4 & 1.0 & 147,616 & 25.8 & 13.1 & 2.7 & 101,445 & 30.5 & 12.9 & 0.3 \\
\hline West & 203,057 & 24.8 & 12.9 & 2.3 & 26,486 & 32.5 & 14.9 & 2.9 & 87,167 & 22.9 & 12.5 & 2.5 & 89,404 & 25.0 & 12.8 & 1.9 \\
\hline \multicolumn{17}{|l|}{ Single Mothers } \\
\hline U.S. Total & $4,460,935$ & 44.4 & 12.5 & 2.4 & 796,464 & 52.1 & 10.1 & 1.5 & $1,682,522$ & 37.5 & 13.2 & 3.0 & $1,981,949$ & 49.2 & 12.9 & 2.1 \\
\hline Northeast & 763,333 & 43.3 & 13.1 & 2.4 & 69,632 & 46.6 & 9.8 & 3.5 & 291,565 & 33.6 & 13.1 & 3.5 & 402,136 & 54.0 & 14.6 & 1.5 \\
\hline Midwest & $1,020,217$ & 48.5 & 12.4 & 2.7 & 200,893 & 49.6 & 9.7 & 1.4 & 357,944 & 40.5 & 13.0 & 3.1 & 461,380 & 56.6 & 13.2 & 3.2 \\
\hline South & $1,890,023$ & 46.2 & 12.6 & 2.1 & 438,066 & 55.4 & 10.0 & 0.5 & 716,621 & 39.5 & 14.0 & 2.5 & 735,336 & 49.5 & 12.6 & 2.5 \\
\hline West & 787,362 & 37.7 & 12.1 & 2.5 & 87,873 & 47.9 & 11.4 & 4.6 & 316,392 & 34.3 & 12.0 & 3.5 & 383,097 & 39.0 & 12.5 & 1.3 \\
\hline
\end{tabular}

Notes

1. All households includes both families with children and without, married couples, single fathers, and single mothers includes only families with children under 18 years of age.

2. Bold and shaded typeface indicates statistically significant change $(p<0.05)$.

3. Levels of urbanization are defined as follows: "rural" consists of geographic components "not in metropolitan or micropolitan statistical area" and "in micropolitan statistical area," suburban includes "in metropolitan statistical area, not in principal city," and central city includes "in metropolitan statistical area, in principal city."

Source: 2007, 2010, \& 2011 American Community Survey 
TABle 2. DisAbled, SENIOR, AND POOR HOUSEHOLDS RECEIVING SNAP IN LAST 12 MONTHS, 2011

\begin{tabular}{|c|c|c|c|c|c|c|c|c|c|c|c|c|c|c|c|c|}
\hline & \multicolumn{4}{|c|}{ All Places } & \multicolumn{4}{|c|}{ Rural } & \multicolumn{4}{|c|}{ Suburban } & \multicolumn{4}{|c|}{ Central City } \\
\hline & $\begin{array}{l}\text { Number of } \\
\text { Households } \\
\text { on SNAP }\end{array}$ & $\begin{array}{l}\text { Percent of } \\
\text { Households }\end{array}$ & $\begin{array}{c}\text { Change } \\
\text { Since } 2007\end{array}$ & $\begin{array}{c}\text { Change } \\
\text { Since } 2010\end{array}$ & \begin{tabular}{|l|} 
Number of \\
Households \\
on SNAP
\end{tabular} & $\begin{array}{l}\text { Percent of } \\
\text { Households }\end{array}$ & $\begin{array}{c}\text { Change } \\
\text { Since } 2007\end{array}$ & $\begin{array}{c}\text { Change } \\
\text { Since } 2010\end{array}$ & \begin{tabular}{|c|}
$\begin{array}{c}\text { Number of } \\
\text { Households } \\
\text { on SNAP }\end{array}$ \\
\end{tabular} & $\begin{array}{l}\text { Percent of } \\
\text { Households }\end{array}$ & $\begin{array}{c}\text { Change } \\
\text { Since } 2007\end{array}$ & $\begin{array}{c}\text { Change } \\
\text { Since } 2010\end{array}$ & $\begin{array}{c}\text { Number of } \\
\text { Households } \\
\text { on SNAP }\end{array}$ & $\begin{array}{l}\text { Percent of } \\
\text { Households }\end{array}$ & $\begin{array}{c}\text { Change } \\
\text { Since } 2007\end{array}$ & $\begin{array}{c}\text { Change } \\
\text { Since } 2010\end{array}$ \\
\hline \multicolumn{17}{|c|}{ Disabled Households } \\
\hline U.S. Total & $6,505,943$ & 23.0 & 7.5 & 1.6 & $1,482,886$ & 24.8 & 6.7 & 1.7 & $2,487,495$ & 18.5 & 7.1 & 1.5 & $2,535,562$ & 28.6 & 8.8 & 1.7 \\
\hline Northeast & $1,232,199$ & 25.1 & 8.1 & 1.7 & 146,761 & 24.8 & 7.1 & 2.1 & 489,042 & 17.4 & 6.8 & 1.6 & 596,396 & 39.6 & 11.7 & 1.5 \\
\hline Midwest & $1,511,288$ & 24.1 & 7.1 & 1.6 & 382,388 & 22.8 & 6.0 & 1.7 & 525,090 & 18.8 & 6.7 & 1.5 & 603,810 & 33.6 & 8.9 & 1.6 \\
\hline South & $2,715,346$ & 24.2 & 7.9 & 1.9 & 786,974 & 26.9 & 6.9 & 1.8 & $1,062,772$ & 20.5 & 7.9 & 1.8 & 865,600 & 27.8 & 9.0 & 1.9 \\
\hline West & $1,047,110$ & 17.8 & 6.8 & 1.3 & 166,763 & 21.0 & 6.6 & 1.1 & 410,591 & 15.5 & 6.2 & 1.0 & 469,756 & 19.2 & 7.4 & 1.7 \\
\hline \multicolumn{17}{|c|}{ Senior Households } \\
\hline U.S. Total & $3,804,132$ & 9.5 & 3.6 & 0.9 & 787,107 & 10.1 & 3.1 & 1.0 & $1,496,698$ & 7.3 & 3.2 & 0.8 & $1,520,327$ & 12.9 & 4.8 & 1.0 \\
\hline Northeast & 832,720 & 10.9 & 4.1 & 0.9 & 76,894 & 9.1 & 2.9 & 0.7 & 316,178 & 6.6 & 3.0 & 0.8 & 439,648 & 21.5 & 7.7 & 1.5 \\
\hline Midwest & 774,917 & 8.7 & 3.2 & 0.7 & 187,285 & 7.9 & 2.6 & 0.8 & 278,216 & 6.5 & 2.8 & 0.5 & 309,416 & 13.7 & 4.6 & 0.9 \\
\hline South & $1,591,726$ & 10.7 & 3.8 & 1.0 & 429,398 & 12.5 & 3.5 & 1.3 & 649,311 & 8.8 & 3.5 & 0.9 & 513,017 & 12.8 & 4.7 & 1.1 \\
\hline West & 604,769 & 7.0 & 3.4 & 0.8 & 93,530 & 8.5 & 3.4 & 0.7 & 252,993 & 6.2 & 3.2 & 0.9 & 258,246 & 7.4 & 3.6 & 0.8 \\
\hline \multicolumn{17}{|c|}{ Households in Poverty } \\
\hline U.S. Total & $7,895,605$ & 47.0 & 10.4 & 2.7 & $1,698,480$ & 51.7 & 10.1 & 2.8 & $2,783,484$ & 43.7 & 11.9 & 3.0 & $3,413,641$ & 47.7 & 9.6 & 2.5 \\
\hline Northeast & $1,365,440$ & 50.5 & 10.5 & 3.2 & 147,987 & 52.2 & 9.9 & 4.5 & 470,438 & 42.5 & 11.0 & 2.9 & 747,015 & 56.9 & 10.5 & 3.1 \\
\hline Midwest & $1,843,220$ & 51.0 & 10.2 & 2.5 & 440,669 & 50.8 & 10.4 & 2.5 & 590,430 & 47.6 & 11.3 & 3.1 & 812,121 & 53.9 & 9.4 & 2.1 \\
\hline South & $3,318,177$ & 48.5 & 11.1 & 3.0 & 917,715 & 53.8 & 10.2 & 2.5 & $1,208,431$ & 46.1 & 13.5 & 3.4 & $1,192,031$ & 47.3 & 10.0 & 3.0 \\
\hline West & $1,368,768$ & 37.6 & 10.1 & 2.2 & 192,109 & 44.8 & 9.6 & 3.4 & 514,185 & 36.9 & 10.7 & 2.4 & 662,474 & 36.3 & 10.1 & 1.9 \\
\hline
\end{tabular}

Notes

1. Bold and shaded typeface indicates statistically significant change $(p<0.05)$.

2. Levels of urbanization are defined as follows: "rural" consists of geographic components "not in metropolitan or micropolitan statistical area" and "in micropolitan statistical area," suburban includes "in metropolitan statistical area, not in principal city," and central city includes "in metropolitan statistical area, in principal city."

Source: 2007, 2010, \& 2011 American Community Survey

Among senior households (households that contain one or more persons aged 60 or older), SNAP receipt reached 9.5 percent in 2011. As with households containing a person with a disability, SNAP rates among this group increased primarily in central cities, with the largest increases in northeastern central cities. SNAP receipt among senior households in northeastern central cities increased from 13.8 percent in 2007 to 21.5 percent in 2011.

Finally, nearly one-half of poor households (47 percent) reported receiving SNAP in 2011, an increase of 10.4 percentage points from 2007. Rates of SNAP receipt were particularly high among the rural poor, at 51.7 percent. ${ }^{8}$ In addition, SNAP is an important support for low-income working households. For example, more than three-quarters of households receiving SNAP contained one or more workers. Workers' use of SNAP in part may reflect overall low wages; while households receiving SNAP tend to have employed members, the median income among SNAP households remained substantially lower than the U.S. median (\$18,014 versus $\$ 50,502$ in 2011). ${ }^{9}$

\section{Policy Implications}

SNAP is increasingly the target of congressional budget cuts, despite the large number of Americans who rely on the program. In 2012, the Senate passed a reauthorization bill that would cut SNAP by $\$ 4.49$ billion over 10 years, which would potentially result in a $\$ 90$ reduction in monthly SNAP benefits for more than half a million households. In addition, the House Committee on Agriculture developed a reauthorization bill that would cut $\$ 16$ billion from the program over 10 years. The number of people who would lose SNAP benefits under just one provision of this bill (eliminating categorical eligibility) is estimated to be between 1.8 million and 3 million, in addition to the half million who would be harmed by the Senate bill cuts. ${ }^{10}$ The American Taxpayer Relief Act (the legislation to resolve the tax components of the "fiscal cliff," enacted at the beginning of January 2013) did not include any cuts to SNAP. However, the debate is merely postponed. This discussion will likely recur in February when Congress will try to find alternatives to the across-the-board budget cuts enacted as part of the Budget Control Act of 2011. Although budget cuts are imminent, policymakers should consider what such cuts would mean to families, including seniors, single parents, the poor, and those with disabilities, who rely on SNAP to meet their nutritional needs.

\section{Data}

This analysis is based on U.S. Census Bureau estimates from the 2007, 2010, and 2011 American Community Survey. ${ }^{11}$ Estimates were produced by aggregating information from detailed tables available on American FactFinder. These estimates are meant to give perspective on SNAP use, but because they are based on survey data, one should use caution when comparing across categories, as the margins of error may place seemingly disparate estimates within reasonable sampling error. ${ }^{12}$ All differences highlighted in this brief are statistically significant $(p<0.05)$.

\section{E N D N O T E S}

1. Austin Nichols, "Poverty in the United States" (Washington, DC: Urban Institute, 2012). Available at www.urban. org/UploadedPDF/412653-Poverty-in-the-United-States.pdf (retrieved October 5, 2012).

2. Dottie Rosenbaum, "SNAP Is Effective and Efficient" (Washington, DC: Center on Budget and Policy Priorities, 2012). Available at www.cbpp.org/cms/index.cfm?fa=view\&id=3239 (retrieved December 19, 2012 ). 
3. Laura Tiehen, Dean Jolliffe, and Craig Gundersen, "Alleviating Poverty in the United States: The Critical Role of SNAP Benefits" (Washington, DC: Economic Research Service, U.S. Department of Agriculture, 2012). Available at www.ers.usda.gov/media/478608/err132_1_.pdf(retrieved December 19, 2012).

4. Kenneth Hanson, "The Food Assistance National Input-Output Multiplier (FANIOM) Model and Stimulus Effect of SNAP” (Washington, DC: Economic Research Service, U.S. Department of Agriculture, 2010). Available at www.ers.usda.gov/media/134117/err103_1_.pdf (retrieved December 19, 2012).

5. Food Research and Action Center, "Nearly 46.3 Million Americans Participated in SNAP in November 2011" (Washington, DC: Food Research and Action Center, 2011). Available at http://frac.org/reports-and-resources/snapfood-stampmonthly-participation-data/ (retrieved October 5, 2012).

6. In 2008, legislative changes resulted in an increase in the minimum monthly benefit: "an increase in the standard deduction for households of three or fewer, and taking into account the full amount of dependent care costs households incur. Retirement and education savings accounts are no longer counted against a household's SNAP eligibility." See Food Research and Action Center, "SNAP/Food Stamp Historic Trends: 19982010" (Washington, DC: Food Research and Action Center, 2012). Available at http://frac.org/federal-foodnutrition-programs/snapfood-stamps/historic-trends-1998-2008/ (retrieved January 3, 2013). In 2009, the American Recovery and Reinvestment Act (ARRA) increased SNAP benefits again, relaxed some eligibility regulations, and provided states with additional funding for SNAP administration.

7. Jin Huang, Baorong Guo, and Youngmi Kim, "Food Insecurity and Disability: Do Economic Resources Matter?" (St. Louis, MO: Center for Social Development, George Warren Brown School of Social Work, Washington University, 2009). Available at http://csd.wustl.edu/Publications/ Documents/WP09-15.pdf (retrieved January 4, 2012). See also James P. Ziliak, Craig Gundersen, and Margaret Heist, "The Causes, Consequences, and Future of Senior Hunger in America" (Alexandria, VA: Meals on Wheels Association of America, 2008). Available at http://www.mowaa.org/ document.doc?id=13 (retrieved January 4, 2013).

8. Not all poor families receive SNAP, although most are eligible. Many poor families who do not receive SNAP may be unsure how to enroll, unaware that they are eligible, want to avoid stigma, or otherwise elect not to enroll. In addition, potential recipients may experience income instability, resulting in fluctuations in their eligibility status. A smaller proportion may be ineligible owing to additional factors such as immigration status or the expiration of time-limited benefits.

9. Carsey Institute analysis of American Community Survey 2011 data, available upon request.
10. Food Research and Action Center, "Farm Bill 2012" (Washington, DC: Food Research and Action Center, 2012). Available at http://frac.org/leg-act-center/farm-bill-2012/ (retrieved January 3, 2013).

11. See U.S. Census Bureau's American Factfinder, http:// factfinder2.census.gov.

12. Ibid.

\section{A B OUT THE AUTHORS}

Jessica A. Carson is a vulnerable families research scientist at the Carsey Institute (jessica.carson@unh.edu).

William W. Meub is a vulnerable families research associate at the Carsey Institute (william.meub@unh.edu).

\section{A C K N O W L E D G M E N T S}

The authors would like to thank Bruce Mallory, Curt Grimm, Beth Mattingly, Amy Sterndale, and Laurel Lloyd at the Carsey Institute for their helpful comments and suggestions; Barbara Ray at Hiredpen, Inc., for editorial assistance; and Jennifer Clayton for assistance with data preparation.

\section{A UNIVERSITY}

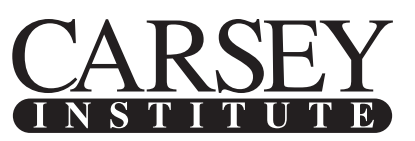

Building knowledge for families and communities

The Carsey Institute conducts policy research on vulnerable children, youth, and families and on sustainable community development. We give policy makers and practitioners timely, independent resources to effect change in their communities.

This work was supported by the Annie E. Casey Foundation, the W. K. Kellogg Foundation, and anonymous donors.

Huddleston Hall

73 Main Street

Durham, NH 03824

(603) $862-2821$

www.carseyinstitute.unh.edu 